\title{
Glacier inventory in Chile: current status and recent glacier variations
}

\author{
Gino Casassa \\ Centro Austral Antártico, Universidad de Magallanes, Casilla 113-D, Punta Arenas, Chile
}

\begin{abstract}
The glacier inventory in Chile covers all the arid north of the country $\left(18^{\circ}\right.$ to $33^{\circ} \mathrm{S}$ ) and the central part down to the lake district $\left(33^{\circ}\right.$ to $41^{\circ} 30^{\prime} \mathrm{S}$ ) except for the Río Maule and Río Itata basins $\left(35^{\circ}\right.$ to $\left.37^{\circ} \mathrm{S}\right)$. The most glaciated region of Chile is Patagonia, characterized by a wet climate, but glacier data are lacking over vast areas of this region. A total area of $5515 \mathrm{~km}^{2}$ has been inventoried in Chile; this does not include Hielo Patagónico Sur (southern Patagonia ice field), by far the largest glaciated area in Chile with an area of $13000 \mathrm{~km}^{2}$, part of which is in Argentina. Including the uninventoried glaciers of Maule, Itata and Patagonia, the total glaciated area in Chile is estimated to be $20715 \mathrm{~km}^{2}$.

Information on glacier variations in the north of Chile is very scarce. In the central and south-central parts, and especially in Patagonia where glacier variations have been most studied, there is ample evidence for general glacier retreat from a neoglacial maximum, although a few glacier advances have been reported. The generalized retreat might be a result of tropospheric warming observed in the second half of the 20 th century.
\end{abstract}

\section{INTRODUCTION}

The geography of Chile is dominated by the Andean Cordillera, which stretches north south for more than $4000 \mathrm{~km}$, from $18^{\circ}$ to $56^{\circ} \mathrm{S}$ (Fig. 1). The elevation of the Andes decreases southward, from $6000-7000 \mathrm{~m}$ in the north and north-central part to $2000 \mathrm{~m}$ in the extreme south (Fig. 2). The climate varies from tropical-dry in the north to wet-temperate in the south, with precipitation ranging from a few $\mathrm{mma}^{-1}$ in the Atacama Desert to nearly $10 \mathrm{~m} \mathrm{a}^{-1}$ on the coast of southern Patagonia.

Consistent with the north-south climate gradient, the regional snow-line elevation decreases southward (Fig. 2). Due to greater precipitation, the extreme south is the most extensively glaciated part of Chile. This region, which corresponds to Patagonia and Tierra del Fuego, includes Hielo Patagónico Norte and Sur the northern and southern Patagonia ice fields) and Cordillera Darwin, altogether about $20000 \mathrm{~km}^{2}$ of ice. The second most glaciated part of Chile is the central part, in the high Andes near Santiago (regions V, VI and metropolitan), where many small mountain glaciers develop with a total area of nearly $1000 \mathrm{~km}^{2}$ (Table 1). The glaciated areas both in the extreme south and in the centre of Chile have mountain peaks that are well over $1000 \mathrm{~m}$ above the regional snow-line (Fig. 2).

Glaciers are of critical importance for Chilean water resources, especially in the central part of the country. In the mid-1970s the Dirección General de Aguas (DGA; General Water Directorate) of the Ministry of Public
Works started to monitor glaciers there as part of its water-resources programme. As a result, mass-balance data since 1975 exist for Glaciar Echaurren Norte near Santiago, the only glacier in Chile monitored for mass balance. In the late 1970 s the DGA started a process of compiling glacier inventories at selected hydrologic basins, the first one being completed by Marangunić (unpublished) in 1979.

Most glacier inventories in Chile have appeared in Spanish, mainly as internal reports of the DGA. The purpose of this paper is to summarize the glacierinventory data and make them available to English readers. Also, a review of recent glacier variations in Chile is presented.

\section{GLACIER INVENTORY}

Glaciers in northern and central Chile occur on the mountain slopes and in the valleys of the high Andes, and are sub-polar in nature. Glaciers in the north are located above $5000 \mathrm{~m}$ (Fig. 2), and each is typically much smaller than $10 \mathrm{~km}^{2}$ in area. Some of the glacier snouts in central Chile are above $3000 \mathrm{~m}$ and exceed $10 \mathrm{~km}^{2}$ in area.

Lliboutry (1956) was the first to make detailed glaciological studies in Chile, including estimates of glaciated areas. Mercer (1967) summarized the distribution of glaciers in Chile, mainly on the basis of Lliboutry's work. Clapperton (1983) and Rabassa and Clapperton (1990) have reviewed the present distribution of glaciers in the southern Andes, the latter with emphasis on Argentine glaciers. 


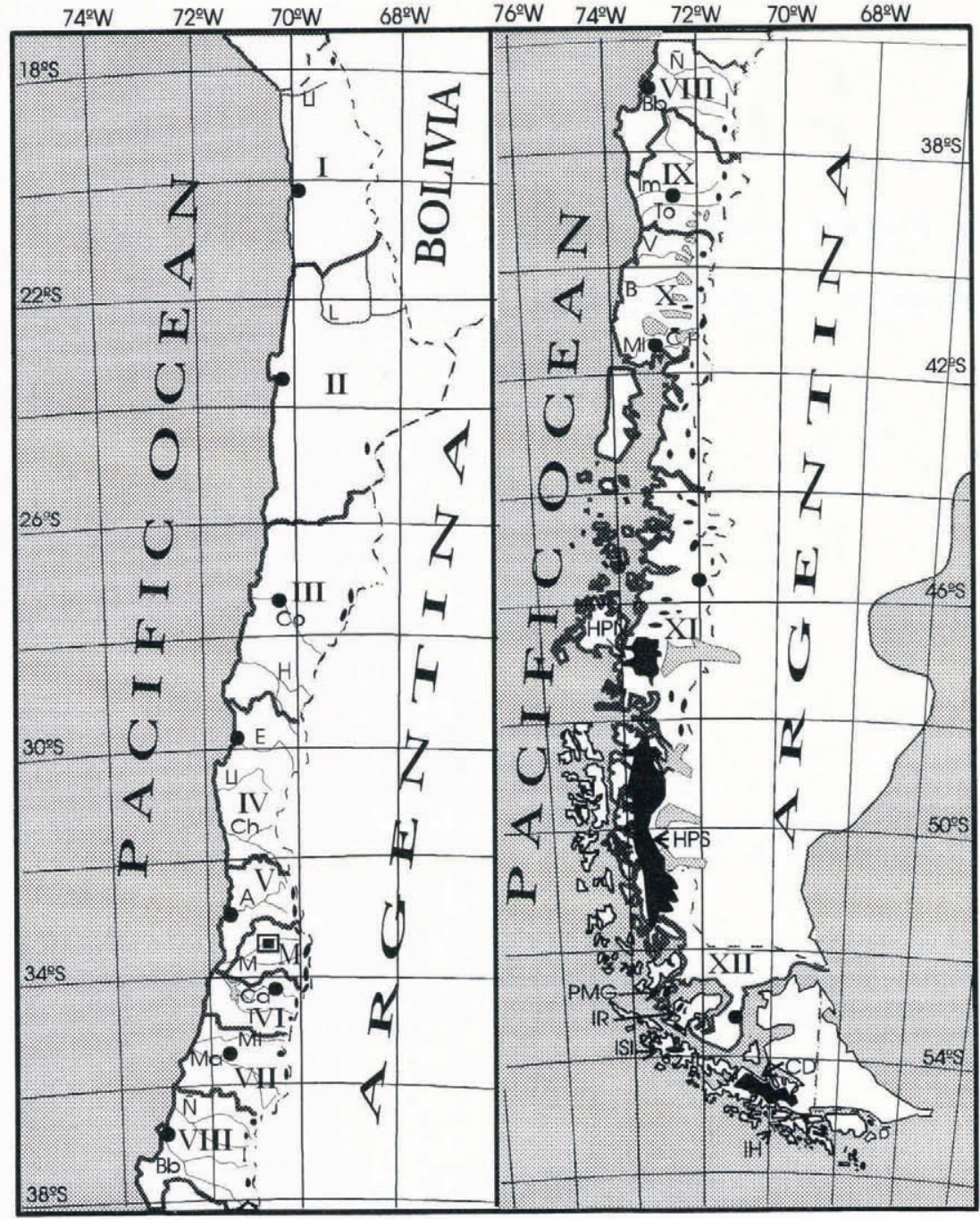

Legend:

$\begin{array}{lll}\mathrm{Ll} & : \text { Río Lluta } \\ \mathrm{L} & : \text { Río Loa } \\ \mathrm{Co} & : \text { Río Copiapó } \\ \mathrm{H} & : \text { Río Huasco } \\ \mathrm{E} & : \text { Río Elqui } \\ \mathrm{Li} & : \text { Río Limarí } \\ \mathrm{Ch} & : \text { Río Choapa } \\ \mathrm{A} & : \text { Río Aconcagua } \\ \mathrm{M} & : \text { Río Maipo } \\ \mathrm{Ca} & : \text { Río Cachapoal } \\ \mathrm{T} & : \text { Río Tinguiririca } \\ \mathrm{Mt} & : \text { Río Mataquito } \\ \mathrm{Ma} & : \text { Río Maule } \\ \mathrm{N} & : \text { Río Nuble } \\ \mathrm{I} & : \text { Río Itata } \\ \mathrm{Bb} & : \text { Río Bío-bío } \\ \mathrm{Im} & : \text { Río Imperial } \\ \mathrm{To} & : \text { Río Toltén } \\ \mathrm{V} & : \text { Río Valdivia } \\ \mathrm{B} & : \text { Río Bueno } \\ \mathrm{Mi} & : \text { Río Maullín } \\ \mathrm{P} & : \text { Río Petrohué } \\ \mathrm{C} & : \text { Río Chamiza } \\ \mathrm{HPN} & : \text { Hielo Patagónico Norte } \\ \mathrm{HPS} & : \text { Hielo Patagónico Sur } \\ \mathrm{PMG} & : \text { Península Muñoz Gamero } \\ \mathrm{IR} & : \text { Isla Riesco } \\ \mathrm{ISI} & : \text { Isla Santa Inés } \\ \mathrm{CD} & : \text { Cordillera Darwin } \\ \mathrm{IH} & : \text { Isla Hoste } \\ & :\end{array}$

Fig. 1. Map of Chile. Roman numerals represent regions. $M$ is the metropolitan region, the square being Santiago. Heavy black lines are political divisions of regions. Black circles represent capitals of regions. The locations of the main glacier areas along the Andes, near the eastern border of Chile, are indicated in black. Thin lines represent rivers. Lakes are shown in grey.

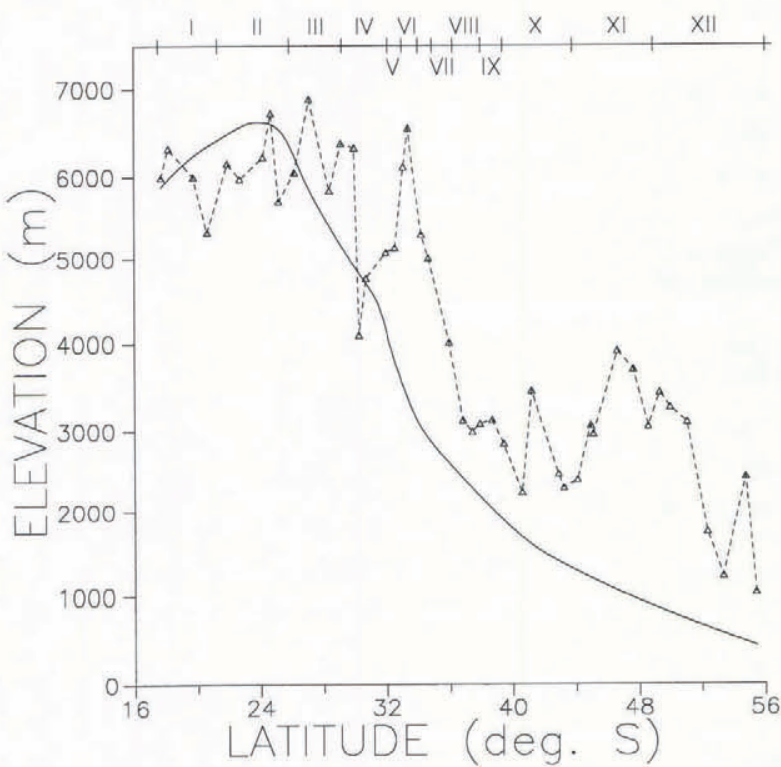

Fig. 2. North-south variation of the regional snow-line on the western side of the Andes (continuous line), based on Nogami (1972), and highest elevation of peaks along the Chilean Andes (dotted line). Triangles respresent individual peaks.
The first glacier inventory in Chile (Marangunić, unpublished) covered the Río Maipo basin $\left(33^{\circ}\right.$ to $34^{\circ} \mathrm{S}$ ), east of Santiago, the Chilean capital. Santiago, a city with about five million inhabitants in 1994, obtains its water resources from the Río Maipo basin. Glaciar Juncal Sur, located within the Río Maipo basin, is $15 \mathrm{~km}$ long (Lliboutry, 1956), the longest glacier in Chile outside Patagonia.

Cachapoal basin, south of Río Maipo, was inventoried by Caviedes (1979). In 1984 the glacier inventories of the Río Aconcagua basin, north of Río Maipo, and the Río Tinguiririca basin, south of Río Cachapoal, were completed by Valdivia (1984, unpublished). A summary of glacier inventories in the Aconcagua, Maipo, Cachapoal and Tinguiririca basins was produced by Valdivia (1984).

The glacier inventory of the Río Mataquito basin, south of Río Tinguiririca, was compiled by Noveroy (unpublished) in 1987. Farther south are the Río Maule and Rio Itata basins $\left(35^{\circ}\right.$ to $\left.37^{\circ} \mathrm{S}\right)$, the only ones in Chile outside Patagonia for which glacier inventories are lacking.

To date, the glacier inventory of central Chile from the Río Aconcagua basin $\left(32^{\circ} 30^{\prime} \mathrm{S}\right)$ to the Rio Mataquito 
Table 1. Inventoried glaciers in Chile

\begin{tabular}{|c|c|c|c|c|c|}
\hline \multicolumn{2}{|c|}{ Region } & Basin & $\begin{array}{l}\text { No. of } \\
\text { glaciers }\end{array}$ & $\begin{array}{l}\text { Area } \\
\left(\mathrm{km}^{2}\right)\end{array}$ & Reference \\
\hline \multicolumn{2}{|l|}{ I } & ${ }^{*}$ & 14 & 29.70 & Garin, 1987 \\
\hline \multicolumn{2}{|l|}{ II } & * & 14 & 12.13 & Garin, 1987 \\
\hline \multicolumn{2}{|l|}{ III } & $*$ & 49 & 66.83 & Garin, 1987 \\
\hline \multicolumn{2}{|l|}{ IV } & * & 11 & 7.02 & Garin, 1987 \\
\hline \multicolumn{2}{|l|}{ V } & Aconcagua & 267 & 151.25 & Valdivia, 1984 \\
\hline \multicolumn{2}{|c|}{ Metropolitan } & Maipo & 647 & 421.90 & Marangunić, unpublished \\
\hline \multicolumn{2}{|c|}{ VI } & Cachapoal & 146 & 222.42 & Caviedes, 1979 \\
\hline \multicolumn{2}{|l|}{ VI } & Tinguiririca & 261 & 106.46 & Valdivia, unpublished \\
\hline \multicolumn{2}{|l|}{ VII } & Mataquito & 81 & 31.91 & Noveroy, unpublished \\
\hline \multicolumn{2}{|c|}{ VIII-IX } & Bío-bio & 29 & 52.37 & Rivera, 1989 \\
\hline \multicolumn{2}{|c|}{ IX } & Imperial & 13 & 18.72 & Rivera, 1989 \\
\hline \multicolumn{2}{|l|}{ IX $\mathrm{X}$} & Toltén & 14 & 68.48 & Rivera, 1989 \\
\hline \multicolumn{2}{|l|}{ IX $-\mathrm{X}$} & Valdivia & 6 & 42.33 & Rivera, 1989 \\
\hline \multicolumn{2}{|l|}{$\mathrm{X}$} & Bueno & 11 & 19.35 & Rivera, 1989 \\
\hline \multicolumn{2}{|l|}{$\mathrm{x}$} & Maullin & 1 & 2.84 & Rivera, 1989 \\
\hline \multicolumn{2}{|l|}{$\mathrm{x}$} & Chamiza & 1 & 1.05 & Rivera, 1989 \\
\hline \multicolumn{2}{|l|}{$\mathrm{x}$} & Petrohué & 12 & 60.57 & Rivera, 1989 \\
\hline \multicolumn{2}{|l|}{ XI } & Hielo Patagónico Norte & $28^{\dagger}$ & 4200 & Aniya, 1988 \\
\hline \multicolumn{3}{|l|}{ Total } & $1600^{\ddagger}$ & 5515.33 & \\
\hline \multicolumn{6}{|c|}{$\begin{array}{l}\text { Only a few glaciers in the north of Chile drain into distinct rivers, so they have not been classified into basins } \\
\text { Garin, 1987). }\end{array}$} \\
\hline \multicolumn{6}{|c|}{$\begin{array}{l}\text { This number reflects the outlet glaciers of Hielo Patagónico Norte. Contiguous mountain glaciers, although } \\
\text { included in the total area, are not counted individually (Aniya, 1988). }\end{array}$} \\
\hline
\end{tabular}

basin $\left(35^{\circ} \mathrm{S}\right)$ is complete. Glaciers occur here both as mountain glaciers and as valley glaciers, commonly including rock glaciers as well. The total number of glaciers inventoried in central Chile is 1402 , with a total area of $934 \mathrm{~km}^{2}$ (Table 1; regions V-VII and metropolitan).

The first glacier inventory covering the north of Chile $\left(18^{\circ}\right.$ to $32^{\circ} \mathrm{S}$ ) was published in 1987 Garín, 1987, unpublished). In contrast to central Chile, only 88 glaciers were identified in the desert-north, with a total area of $116 \mathrm{~km}^{2}$ (Table 1; regions $\mathrm{I}-\mathrm{IV}$ ). These glaciers are located on isolated peaks, mainly volcanoes, which rise above the altiplano. Rivers draining from them are small and generally disappear before reaching the Pacific Ocean. The largest glaciated expanse in the north occurs on Cerro Los Tronquitos (height $5642 \mathrm{~m}, 28^{\circ} 32^{\prime} \mathrm{S}$ ), an area of $8.8 \mathrm{~km}^{2}$ (Garín, 1987).

In the south, a glacier inventory for the basins between Río Bío-bío and Río Petrohué ( $37^{\circ}$ to $41^{\circ} 30^{\prime} \mathrm{S}$ ) was compiled in 1989 (Rivera, 1989). A total of 82 glaciers was identified, covering an area of $266 \mathrm{~km}^{2}$ (Table 1; regions VIII-X), all of them occurring on mountain slopes, mainly volcanoes. The largest glacier $\left(51 \mathrm{~km}^{2}\right)$ occurs on Monte Tronador (height $3003 \mathrm{~m}$ ). In spite of the large precipitation in southern Chile (about $2 \mathrm{ma}^{-1}$ at Valdivia, $\left.40^{\circ} \mathrm{S}\right)$, glaciation here is limited by the low elevation of the Andes (see Fig. 2).

In Patagonia, south of $41^{\circ} 30^{\prime} \mathrm{S}$, the Andes rise to over $3000 \mathrm{~m}$ in many areas (Fig. 2). Together with high precipitation this favors the development of glaciers. Glaciers in Patagonia are typically temperate with high ablation. In addition to many mountain glaciers and small ice caps, two major ice fields exist in this region: Hielo Patagónico Norte $\left(46^{\circ} 25^{\prime}\right.$ to $47^{\circ} 35^{\prime} \mathrm{S}$ ) and Hielo Patagónico Sur $\left(48^{\circ} 15^{\prime}\right.$ to $\left.51^{\circ} 35^{\prime} \mathrm{S}\right)$. The first glacier inventory here describes the glaciers of Hielo Patagónico Sur that drain to Argentina between $47^{\circ} 30^{\prime} \mathrm{S}$ and $51^{\circ} \mathrm{S}$ (Bertone, 1960).

For Hielo Patagónico Norte, which lies completely within Chile, the first glacier inventory was compiled by Valdivia $(1979 a, b)$ in a project sponsored by the World Glacier Inventory Program in cooperation with the DGA. The inventory was based on $1: 250000$ scale maps, but no field data were available with which to estimate ablation and accumulation areas. Aniya (1988) compiled a detailed glacier inventory of Hielo Patagónico Norte based on 1:50000 scale maps and field data of equilibrium-line altitudes. Twenty-eight outlet glaciers with areas ranging from 6 to $765 \mathrm{~km}^{2}$ were inventoried by Aniya (1988), with a total ice-field area of about $4200 \mathrm{~km}^{2}$ (Table 1; region XI).

With this, the total area of inventoried glaciers in Chile, from $18^{\circ}$ to $35^{\circ} \mathrm{S}$ and $37^{\circ}$ to $41^{\circ} 30^{\prime} \mathrm{S}$, amounts to $5515 \mathrm{~km}^{2}$ (Table 1 ).

Vast tracts of Patagonia are not yet inventoried, in particular continental Chiloé and Aysén, Hielo Patagónico Sur, glaciers off the coast of Magallanes, and Cordillera Darwin in Tierra del Fuego. The area of Hielo 
Patagónico Sur is known, viz. $13000 \mathrm{~km}^{2}$ (Aniya and others, 1992). The disputed border between Chile and Argentina runs through Hielo Patagónico Sur, approximately $90 \%$ of which lies in Chile according to the Chilean claim (Martinic, 1982), and about 75\% according to the Argentine claim.

A rough estimate of glacier extent in uninventoried areas is made based on approximations from maps at 1:500000 scale and preliminary data of Lliboutry (1956). Results are presented in Table 2, showing an uninventoried glacier area of $15200 \mathrm{~km}^{2}$. Adding this value to the inventoried glacier area results in a total estimated glacier area in Chile of $20715 \mathrm{~km}^{2}$.

\section{GLAGIER VARIATIONS}

Unlike the Alps, Chilean glaciers are located far from human settlements. Thus, early descriptions of glaciers are very scarce. Patagonia is an exception because of explorations in the fjords by early European navigators, who have given a few descriptions of glaciers since 1557 (Martinic, 1982).

Glaciar San Rafael in Hielo Patagónico Norte has the longest history of glacier variations in Chile, dating back to 1675 with a description by Spanish navigator de Vea (Brüggen, 1950; Casassa and Marangunić, 1987). Systematic explorations on glaciers and observations of glacier variations started in the late 19th century. Lliboutry (1956) carried out the first detailed study of snow and ice in Chile, compiling maps and quantifying the extent of many glacierized areas in the northern and central regions and in Patagonia, and also describing recent glacier variations. Clapperton (1990) and Rabassa and Clapperton (1990) reviewed Holocene glacier variations in South America. Mercer (1962, 1967) summarized glacier variations in the Chilean Andes, mainly referring to Lliboutry's work. Since then, modern glacier variations have received the attention of several scientific parties, which have concentrated almost exclusively on Patagonia.

In the north, glacier variations are almost unknown, partly because of the very limited extent of glaciers in this arid region. Lliboutry (1956) and Lliboutry and others (1958) concluded that glaciers on Nevado Tres Cruces (height $6620 \mathrm{~m}$ ) did not change substantially from 1937 to 1956, nor glaciers on Cerro Tórtolas from 1935 to 1955. Mercer (1962) states that glaciers in the north did not recede from 1944 to 1964 . An exception is glacier tongues to the west of Cerro Tórtolas, which receded from 4150 to over $4800 \mathrm{~m}$ in elevation from 1925 to 1955 according to descriptions by mountaineers (Lliboutry, 1956, p. 306).

South of $32 \mathrm{~S}$, in the Andes of Santiago and Rancagua, there is evidence for general retreat and thinning of glaciers during the 20th century, based on descriptions by explorers and mountaineers and studies by Lliboutry (1956) and Lliboutry and others (1958). Inspection of mass-balance data of Glaciar Echaurren from 1975 to 1983 shows a large yearly variation, but no definite trend (Peña and others, 1984). In spite of the scarce vegetation, a distinct trim line showing the extent of a recent neoglacial advance is clearly visible on most glaciers. Contrary to the general trend, four glaciers were advancing from 1920 to 1955: Juncal Sur, Museo

Table 2. Uninventoried glaciers in Chile

\begin{tabular}{|c|c|c|c|}
\hline Latitude & Region & Description & $\begin{array}{l}\text { Estimated area } \\
\mathrm{km}^{2}\end{array}$ \\
\hline $35^{\circ}$ to $37^{\circ} \mathrm{S}$ & VII-VIII & $\begin{array}{l}\text { Rio Maule and Rio Itata basins; glaciers limited to a few high } \\
\text { peaks (e.g. Volcán San Pedro, } 3499 \mathrm{~m} \text { ) }\end{array}$ & 50 \\
\hline $41^{\circ} 30^{\prime}$ to $45^{\circ} 30^{\prime} \mathrm{S}$ & $\mathrm{X}-\mathrm{XI}$ & $\begin{array}{l}\text { Continental Chiloé and northern Aysén; three main ice caps } \\
\text { on Mount Michinmávida }(2470 \mathrm{~m}) \text {, Mount Yanteles (2042 m) } \\
\text { and Mount Melimoyu ( } 2400 \mathrm{~m} \text { ) (Lliboutry, 1956), plus many } \\
\text { smaller mountain glaciers }\end{array}$ & $250^{*}$ \\
\hline $45^{\circ} 30^{\prime}$ to $49^{\circ} \mathrm{S}$ & $\mathrm{XI}$ & $\begin{array}{l}\text { North, east and southeast of Hielo Patagónico Norte, and } \\
\text { northeast of Hielo Patagónico Sur; many mountain glaciers, } \\
\text { e.g. Volcán Hudson, Cerro San Lorenzo }(3700 \mathrm{~m})\end{array}$ & 400 \\
\hline $48^{\circ} 15^{\prime}$ to $51^{\circ} 35^{\prime} \mathrm{S}$ & $\mathrm{XI}-\mathrm{XII}$ & $\begin{array}{l}\text { Hiclo Patagónico Sur, total area } 13000 \mathrm{~km}^{2} \text { (Aniya and } \\
\text { others, 1992), of which } 90 \% \text { is claimed by Chile (Martinic, } \\
1982 \text {. }\end{array}$ & 11700 \\
\hline $51^{\circ} 45^{\prime}$ to $52 \mathrm{~S}$ & $\mathrm{XII}$ & $\begin{array}{l}\text { Cordillera Sarmiento; ice caps and mountain glaciers, first } \\
\text { explored by Miller (1994) }\end{array}$ & 100 \\
\hline $52^{\circ} 40^{\prime}$ to $53^{\circ} \mathrm{S}$ & XII & $\begin{array}{l}\text { Peninsula Muñoz Gamero; ice field on southwestern part of } \\
\text { peninsula }\end{array}$ & $200^{*}$ \\
\hline $52^{\circ} 50^{\prime}$ to $53^{\circ} 20^{\prime} \mathrm{S}$ & XII & Isla Riesco; mountain glaciers & 100 \\
\hline $53^{\circ} 45^{\prime}$ to $54^{\circ} \mathrm{S}$ & XII & Isla Santa Inés; ice field on eastern part of island & $250^{* \prime}$ \\
\hline $54^{\circ} 20^{\prime}$ to $54^{\circ} 50^{\prime} \mathrm{S}$ & $\mathrm{XII}$ & $\begin{array}{l}\text { Cordillera Darwin; } 160 \mathrm{~km} \text { long ice field, } 25 \mathrm{~km} \text { wide in central } \\
\text { part }\end{array}$ & 2000 \\
\hline $55^{\circ} 10^{\prime} \mathrm{S}$ & XII & $\begin{array}{l}\text { Isla Hoste; ice cap located on Peninsula Cloue, western part of } \\
\text { the island, plus smaller glaciers to the east }\end{array}$ & 150 \\
\hline Total & & & 15200 \\
\hline
\end{tabular}


and Colina glaciers in the Maipo basin, and Glaciar Universidad in the head-waters of the Cachapoal and Tinguiririca basins (Lliboutry, 1956; Mercer, 1962). Reasons for these advances are unclear.

In the south of Chile between $37^{\circ}$ and $41^{\circ} 30^{\prime} \mathrm{S}$, Lliboutry (1956) also reports clear evidence of glacier retreat. In particular, the northern glacier of Volcán Lanin is now limited to the summit area, as opposed to 1897 when it extended down the mountain slope (Lliboutry, 1956). Glaciar Casa Pangue on Monte Tronador $(3554 \mathrm{~m})$ reached an elevation of $370 \mathrm{~m}$ in 1911 (Lliboutry, 1956), whereas now it only reaches $556 \mathrm{~m}$ (Rivera, 1989).

Regarding Patagonia, south of Puerto Aysén, mention should be made of studies by Lliboutry $(1953,1956)$ and Mercer $(1962,1964,1968,1970,1976)$, and particularly those by Japanese expeditions (Iwata, 1983; Aniya and Enomoto, 1986; Sweda, 1987; Aniya, 1988; Aniya, 1992; Aniya and Skvarca, 1992; Aniya and others, 1992; Kadota and others, 1992; Malagnino and Strelin, 1992). Warren and Sugden (1993) carried out a comprehensive review of glacier variations in Hielo Patagónico Norte and Sur. The general trend in the Patagonian ice fields is retreat from a neoglacial maximum that occurred in the mid- to late 19th century (Warren and Sugden, 1993). This neoglacial maximum is clearly indicated by trim lines sometimes more than $100 \mathrm{~m}$ above the present glacier surface. The general retreat varies spatially in extension and timing (Marangunić, 1964a,b; Aniya, 1988; Warren and Sugden, 1993).

Except for Glaciar San Rafael, which stopped retreating in 1990 (Warren, 1993), all glaciers in Hielo Patagónico Norte are presently retreating (Aniya, 1992). In Hielo Patagónico Sur as well most glaciers are retreating (Aniya and others, 1992), with drastic thinning also observed on many. In particular, Kadota and others (1992) have measured a thinning rate of $4 \mathrm{ma}^{-1}$ on Glaciar Tyndall from 1985 to 1990. Anomalous cases of advance in Hielo Patagónico Sur are Glaciar Pio XI (also named Brüggen), which recently reached its maximum Holocene extent Clapperton, 1990) and now is breaking into new forest (Rivera, 1992; Warren and Sugden, 1993), and Glaciar Moreno, draining to Argentina, which has been stable with periods of advance when it has dammed the southern arm of Lago Argentino.

Glacier variations in Cordillera Darwin in Tierra del Fuego have only been studied recently (Holmlund, 1993). Holmlund reports that glaciers with accumulation areas facing east and north, such as Glaciar Marinelli, the largest glacier in Cordillera Darwin, are retreating, while glaciers facing south and west are relatively stable and in one case advancing.

In summary, except for a few advancing glaciers - in the Andes near Santiago, in the Patagonian ice fields and in Cordillera Darwin - the general trend in Chile south of $32 \mathrm{~S}$ is for retreat of glaciers from a recent neoglacial maximum. This retreat may be explained by temperature increase in the troposphere during the second half of the 20 th century, as inferred from radiosonde data of Puerto Montt, $41^{\circ} \mathrm{S}$ (Fuenzalida and others, 1993). The advance reported for a few glaciers might be due to local reasons unrelated to climatic changes.

\section{ACKNOWLEDGEMENTS}

Appreciation is expressed to C. Garín, J. Quinteros and F. Escobar of Dirección General de Aguas, Santiago, who contributed valuable data. Travel to the symposium in Columbus, U.S.A., was funded by Fundación Andes, Chile, through the "Programa de Asistencia a Eventos Internacionales Fundación Andes/Conicyt". The stay in Columbus was funded by Universidad de Magallanes (UMAG). Mr A. Oyaneder of UMAG drafted Figure 1.

\section{REFERENCES}

Aniya, M. 1988. Glacier inventory for the Northern Patagonia lcefield, Chile, and variations $1944 / 45$ to $1985 / 86$. Arct. Alp. Res. 202 , 179 187.

Aniva, M. 1992. Glacier variation in the Northern Patagonia Icefield, Chile, between 1985/86 and 1990/91. Bull. Glacier Res. 10, 8390.

Aniva, M. and H. Enomoto. 1986. Glacier variations and their causes in the Northern Patagonia Icefield, Chile, since 1944. Arct. Alp. Res. 18 (3), 307-316.

Aniya, M. and P. Skvarca. 1992. Characteristics and variations of Upsala and Moreno glaciers, southern Patagonia. Bull. Glacier Res., $10,39-53$.

Aniya, M., R. Naruse, M. Shizukuishi, P. Skvarca and G. Casassa. 1992. Monitoring of recent glacier variations in the Southern Patagonia Ieefield, utilizing remote sensing data. Int. Arch. Photogramm. Remote Sensing. 24 B7), 87-94.

Bertone, M. 1960. Inventario de los glaciares existentes en la iertiente Argentina entre los paralelos $47^{\circ} 30^{\prime}$ y $51^{\circ} \mathrm{S}$. Buenos Aires, Instituto Nacional del Hielo Continental Patagónico. Publicación 3.

Brüggen, J. O. 1950. Fundamentos de la geología de Chile. Santiago, Instituto Geográfico Militar.

Casassa, G. and C. Marangunic, 1987. Exploration history of the Northern Patagonia Icefield. Bull. Glacier Res. 4, $163-175$.

Caviedes, J. 1979. Inventario de glaciares en la hoya del Rio Cachapoal y predicción de la escorrentia de deshielo. Andes centrales. Thesis, Universidad de Chile.

Clapperton, C. M. 1983. The glaciation of the Andes. Quat, Sci. Rev., 2. $83-155$.

Clapperton, C. M. 1990. Quaternary glaciations in the Southern Hemisphere: an overview. Quat. Sci. Rev., 9 2-3). 299-304.

Fuenzalida, H., B. Rosenbluth and R. Sanguinetti. 1993. Temperature variations in Chile and austral South America during the present century and its relation with rainfall. In Intermational Workshop The Quaternary of Chile, Universidad de Chile, Santiago, Chile. Abstracts, 18.

Garin, C. 1987. Inventario de glaciares de los Andes Chilenos desde los 18 a los 32 de latitud sur. Revista de Geografía. Norte Grande, 14, 3448.

Garin. C. Unpublished. Inventario de glaciares de los Andes Chilenos desde $\operatorname{los} 18^{\circ}$ a $\operatorname{los} 32^{\circ}$ de latitud sur. Santiago, Dirección General de Aguas. Publicación Interna, EH86/5.

Holmlund, P. 1993. Recent glacier fluctuations in the Darwin Cordillera. In Internalional Workshop. The Quatemary of Chile, Unizersidad de Chile, Santiago, Chile. Abstracts, 14.

Iwata, S. 1983. Further advance of Pio XI Glacier. In Naruse. R., ed. Glaciological and meteorological studies in Palagonia. Chile. by Japanese research expeditions in 1967 1982. Nagoya, Japanese Society of Snow and Ice, $14 \quad 17$.

Kadota, T., R. Naruse, P. Skvarca and M. Aniya. 1992. Ice flow and surface lowering of Tyndall Glacier, southern Patagonia. Bull. Glacier Res. 10, 63-68.

Lliboutry, L. 1953. More about advancing and retreating glaciers in Patagonia. 7. Glaciol., 2 13), 168-172.

Lliboutry. L. 1956. Niezes y glaciares de Chile. Santiago. Ediciones de la Universidad de Chile.

Lliboutry, L., O. González and J. Simken. 1958. Les glaciers du désert Chilien. International Association of Scientific Hydrology Publication 46 General Assembly of Toronto 1957 - Snow and Ice), 291-300.

Malagnino, E. and J. Strelin. 1992. Variations of Upsala Glacier in southern Patagonia since the Late Holocene to the present. In Naruse, R. and M. Aniva, eds. Glaciological researches in Patagonia, 1990. Nagoya, Japanese Society of Snow and Ice, 6185.

Marangunić, C. 1964a. Glaciación actual de los Andes Patagónicos. Revista Sociedad Geologica de Chile 18, 1-12. 
Marangunić, C. 1964b. Observaciones glaciológicas y geológicas en la zona del Paso de los Cuatro Glaciares, Hielo Patagónico Sur. (Thesis, Universidad de Chile.)

Marangunić, C. Unpublished. Inventario de glaciares en la hoya del Rio Maipo. Santiago, Dirección General de Aguas. (Publicación $\mathrm{G}-2$.)

Martinic, M. 1982. Hielo Patagónico Sur. Publicaciones del Instituto de la Patagonia, Serie Monografias 12.

Mercer, J. H. 1962. Glacier variations in the Andes. Glaciol. Notes 12, 9-31.

Mercer, J. H. 1964. Advance of a Patagonian glacier. J. Glaciol., 5(38), 267-268.

Mercer, J.H. 1967. Southern Hemisphere glacier allas. Natick, MA, U.S. Army Natick Laboratories. (Technical Report W-67-76-ES.)

Mercer, J.H. 1968. Variations of some Patagonian glaciers since the Late-Glacial. Am. J. Sci., 266 2), 91-109.

Mercer, J.H. 1970. Variations of some Patagonian glaciers since the Late-Glacial: II. Am. J. Sci., 2696 ), 1-25.

Mercer, J.H. 1976. Glacial history of southernmost South America. Quat. Res., 6 (2), 125-166.

Miller, J. 1994. Chile's uncharted Cordillera Sarmiento. National Geographic Magazine, $\mathbf{1 8 5}$ (4), 116-130.

Nogami, M. 1972. The snow line and climate during the last glacial period in the Andes mountains. The Quaternary Research, 11(2). [In Japanese.]

Noveroy, C. Unpublished. Inventario de glaciares de la hoya del Río Mataquito. Santiago, Dirreción General de Aguas. Publicación Interna EH87/1.

Peña, H., F. Vidal and F. Escobar. 1984. Caracterización del manto nival y mediciones de ablación y balance de masa en Glaciar Echaurren Norte. In Proceedings. Jornadas de Hidrologia de Nieves y
Hielos en América del Sur, Programa Hidrológico Internacional. Vol. I, I $12.1-\mathrm{I} 12.16$.

Rabassa, J. and C. M. Clapperton. 1990. Quaternary glaciations of the southern Andes. Quat. Sci. Rev., 9, $153-174$.

Rivera, A. 1989. Inventario de glaciares entre las cuencas de los ríos Bío Bío y Petrohué. Su relación con el volcanismo activo: caso Volcán Lonquimay. (Thesis, Universidad de Chile.)

Rivera, A. 1992. El Glaciar Pio XI: avances y retrocesos, el impacto sobre su entorno durante el presente siglo. Rev. Geogr. Chile Terra Australis, 36, $33-62$.

Sweda, T. 1987. Recent retreat of Soler Glacier, Patagonia as seen from vegetation recovery. Bull. Glacier Res. 4, 119-124.

Valdivia, P. 1979a. Los Hielos Patagónicos Norte, inventario de glaciares. In Segundo Congreso Geologico Chileno, 6-11 Agosto 1979. Arica, Chile. Arica, 161-170.

Valdivia, P. 1979b. The North Patagonia Icefield glacier inventory. Zürich, Temporary Technical Secretariat for World Glacier Inventory (UNESCO), 1L-6L, 1R-6R.

Valdivia, P. 1984. Inventario de glaciares. Andes de Chile central $\left(32^{\circ}-\right.$ $35^{\circ}$ Lat. S), hoyas de los Ríos Aconcagua, Maipo, Cachapoal y Tinguiririca. In Proceedings. Jornadas de Hidrologia de Nieves y Hielos en América del Sur, Programa Hidrológico Internacional, Vol. I, I 6.1-I 6.24.

Valdivia, P. Unpublished. Inventario de glaciares. Hoya del Río Tinguiririca, VI Región. Santiago, Dirección General de Aguas. Publicación Interna.

Warren, C. R. 1993. Rapid recent fluctuations of the calving San Rafael Glacier, Chilean Patagonia: climatic or non-climatic? Geogr. Ann., 75A $\mathbf{A}), 111-125$.

Warren, C.R. and D.E. Sugden. 1993. The Patagonian icefields: a glaciological review. Arct. Alp. Res., 25 4), 316-331. 